\title{
Analisis Perbaikan Proses Shipping Kursi Mobil Dalam Upaya Mengurangi Frekuensi Terjadinya Delay Delivery
}

\author{
M. Yani Syafei; Andi Muhamad Yusuf \\ Faculty of Engineering, Industrial Engineering Department, President University \\ Jl. Ki Hajar Dewantara \\ Kota Jababeka,Cikarang, Bekasi - Indonesia 17550 \\ Email: yanisyafei@president.ac.id ; andimuhamadyusuf01@yahoo.com
}

\begin{abstract}
Abstrak
PT. FSI merupakan perusahaan yang bergerak di bidang otomotif. Meningkatnya permintaan dan upaya memenuhi kepuasan pelanggan, maka mendorong perusahaan untuk terus melakukan berbagai upaya perbaikan di antaranya pada bagian departemen pengiriman (shipping) yaitu dengan memperlancar pengiriman produk ke pelanggan (customer). Salah satu penyebab terjadinya kemacetan aliran pengiriman produk ke pelanggan (delay delivery) adalah terdapat permasalahan di proses pre-delivery yaitu pada mesin conveyor storage. Mesin conveyor storage adalah mesin yang menghubungkan dari hasil proses produksi ke tempat penyimpanan barang sementara yang kemudian dimasukkan ke dalam truk untuk dikirim ke konsumen. Tujuan yang dicapai dalam penelitian ini adalah menganalisis penyebab terjadinya delay delivery pada proses shipping kursi mobil di mesin conveyor storage dan melakukan perbaikan (improvement) untuk menurunkan frekuensi base pallet macet di mesin conveyor storage dengan menggunakan metode six sigma. Berdasarkan hasil penelitian serta analisis yang telah dilakukan ternyata kasus base pallet macet di mesin conveyor storage merupakan penyebab terjadinya delay delivery ke customer dan kemudian dilakukan perbaikan untuk mengatasi atau mengurangi frekuensi permasalahan base pallet macet di mesin conveyor storage dengan menambahkan sponge pada shaft roller conveyor. Penambahan gulungan sponge tersebut dimaksudkan untuk menambah power saat perpindahan base pallet antar station.
\end{abstract}

Kata kunci: Conveyor storage, shipping, delay delivery, base pallet.

\section{Aabstract}

PT. FSI is a company engaged in the automotive sector. Increased demand and efforts to meet customer satisfaction, then encouraging companies to continue to make various improvements including the shipping department, which is to facilitate the delivery of products to customers. One of the causes of the delay in the delivery of products to customers (delay delivery) is that there is a problem in the pre-delivery process, namely the storage conveyor machine. A storage conveyor machine is a machine that connects from the results of the production process to the temporary storage of goods which are then put into trucks to be sent to consumers.

The objective achieved in this study was to analyze the causes of the delay delivery in the process of shipping car seats on conveyor storage machines and make improvements to reduce the jammed base pallet frequency on the storage conveyor machine using the six sigma method. Based on the results of the research and analysis that have been carried out, it turns out that the case of the jammed base pallet on the conveyor storage machine is the cause of delay delivery to the customer and then make improvement to overcome or reduce the frequency of jammed base pallet problems on the storage conveyor machine by adding sponges to the shaft roller conveyor. The addition of sponge rolls is intended to increase power when moving base pallet between stations.

Keywords: Conveyor storage, shipping, delay delivery, base pallet.

\section{Pendahuluan}

Pengertian distribusi adalah kegiatan memindahkan produk dari sumber ke konsumen akhir dengan saluran distribusi pada waktu yang tepat (Assauri, 2004). Jika terjadi keterlambatan dalam pada proses pengiriman barang maka akan menyebabkan terhentinya proses produksi di proses selanjutnya ataupun di pelanggan (customer). Penilaian buruk dari pelanggan juga akan melekat pada diri perusahaan sebagai pemasok (supplier) karena tidak dapat memenuhi kebutuhan pelanggan dengan baik. Selain menghambat proses produksi di pelanggan (customer), pelanggan juga harus membuang sumber daya yang ada karena harus menunggu barang dari pemasok (supplier) akibat keterlambatan pengiriman. Dari sumber daya yang terbuang 
(sia-sia) tersebut maka perusahaan pun harus mengalami kerugian karena harus mengeluarkan biaya tanpa menghasilkan output (barang jadi).

PT. FSI merupakan perusahaan manufaktur yang memproduksi kursi mobil (seat) untuk kendaraan roda empat. Perusahaan ini memproduksi produk untuk memenuhi kebutuhan pasar dalam negeri yaitu Indonesia serta melakukan ekspor produk ke induk perusahaan yaitu company group yang berlokasi di Jepang. Permasalahan yang terjadi di PT. FSI yaitu terjadinya delay delivery pada saat proses di mesin conveyor storage. Hal ini menyebabkan kekhawatiran bagi manajemen jika sampai terjadi stop line di customer karena hal tersebut. Oleh karena itu, masalah ini harus segera diatasi dan ditemukan solusi terbaiknya.

Berdasarkan data dari perusahaan bahwa masalah yang paling tinggi terjadi adalah pada proses di mesin conveyor storage yang berada di divisi shipping. Mesin conveyor storage shipping adalah mesin yang menghubungkan dari line assembly ke shipping (truk) yang akan mengirim barang ke customer. Mesin ini adalah mesin baru pengganti dari manual shipping yang sebelumnya dilakukan secara manual oleh beberapa operator shipping. Dengan adanya mesin ini pekerjaan dapat dilakukan lebih cepat dan mengurangi kebutuhan operator. Mesin conveyor storage ini langsung terhubung dengan sistem haisin (Just In Time) yang terhubung langsung dengan server customer yaitu PT. Astra Daihatsu Motor (ADM), sehingga jika terjadi masalah pada mesin conveyor storage dapat mengakibatkan ADM stop line. Mesin conveyor storage shipping mempunyai sistem yaitu dengan mengkombinasi antara program PLC (Programmable Logic Controller), barcode reader, serta sistem haisin. Penelitian dilakukan pada pre-delivery pada mesin conveyor storage di PT. Fuji Seat Indonesia dikarenakan mesin ini sangat penting karena berhubungan langsung dengan pengiriman barang ke customer.

\section{Metode Penelitian}

Beberapa data dikumpulkan untuk melakukan analisis. Data yang digunakan dalam penelitian ini bersumber dari pengamatan langsung dilapangan dan wawancara kepada manager, staff serta operator. Analisis data dilakukan dengan metode berdasarkan teori-teori berikut.

\subsection{Six Sigma}

Six Sigma adalah suatu tindakan yang dilakukan secara kontinyu dalam rangka perbaikan untuk mengurangi pemborosan serta cacat produk dalam hasil produksi. Six sigma bertujuan untuk meningkatkan usaha atau bisnis untuk memenuhi kepuasan pelanggan dengan cara meningkatkan kualitas hasil produk dan memproduksi produk tanpa cacat (Pyzdek, 2003).

Strategi six sigma yang diciptakan oleh Dr. Mikel Harry dan Richard Schroeder disebut sebagai The Six Sigma Breakthrought Strategy. Strategi ini merupakan metode sistematis yang menggunakan pengumpulan data dan analisis statistik untuk menentukan sumber-sumber variasi dan cara-cara untuk menghilangkannya (Pande, et al., 2003). Six sigma dibagi menjadi dua perspektif yaitu perspektif statistik dan perspektif metodologi.

\subsubsection{Perspektif Statistik}

Six Sigma dalam statistik dikenal dengan standar deviasi yang menyatakan nilai sebagai simpangan baku terhadap nilai tengah. Suatu proses dikatakan baik apabila tidak keluar dari batas-batas yang telah ditentukan dan disepakati Proses Six Sigma adalah proses yang hanya menghasilkan 3.4 DPMO (defect permillion opportunity), dimana nilai DPMO dan Sigma disajikan pada Tabel 1.

Tabel 1. Six Sigma Dalam Perspektif Statistik

\begin{tabular}{|c|c|c|}
\hline $\begin{array}{c}\text { Yield } \\
\text { (probabilitas tanpa cacat) }\end{array}$ & $\begin{array}{c}\text { DPMO } \\
\text { (defect permillion opportunity) }\end{array}$ & Sigma \\
\hline $30.9 \%$ & 690.000 & 1 \\
\hline $69.2 \%$ & 308.000 & 2 \\
\hline $93.3 \%$ & 66.800 & 3 \\
\hline $99.4 \%$ & 6.210 & 4 \\
\hline $99.98 \%$ & 320 & 5 \\
\hline $99.9997 \%$ & 3.4 & 6 \\
\hline
\end{tabular}

\subsubsection{Perspektif Metodologi}


Metode yang digunakan dalam six sigma yaitu DMAIC (Define, Measure, Analyze, Improve, Control). DMAIC merupakan jantung analisis six sigma yang menjamin voice of customer berjalan dalam keseluruhan proses sehingga produk yang dihasilkan memuaskan pelanggan (Thomas Pyzdek, 2000).

- Define yaitu menentukan masalah yang akan diselesaikan atau dicari solusinya.

- Measure yaitu melakukan pengukuran tingkat kecacatan yang terjadi dalam proses produksi.

- Analyze yaitu menganalisis faktor-faktor penyebab masalah/cacat yang terjadi.

- Improve yaitu meningkatkan proses hasil produksi dengan hasil produk yang baik atau kualitas yang baik dan menghilangkan faktor-faktor penyebab terjadinya cacat.

- Control yaitu mengontrol kinerja proses produksi belangsung agar produk yang dihasilkan selalu baik, kualitas baik dan menjamin tidak muncul cacat dalam proses produksi.

\subsection{QC Seven Tools (7 Alat Pengendali Kualitas)}

QC Seven Tools atau Tujuh alat Pengendalian Kualitas adalah alat-alat statistik yang dipergunakan untuk meningkatkan kualitas dan untuk mengatasi permasalahan-permasalahan yang muncul dalam proses manufacturing (Ishikawa, 1985). Dengan adanya QC seven tools ini, kita dapat mengidentifikasikan masalah dan mempersempitkan ruang lingkup masalah tersebut serta menemukan faktor penyebab terjadinya masalah. Dengan demikian kita dapat dengan mudah mencari tindakan perbaikan dan pencegahan dengan tepat sehingga permasalahan yang sama tidak akan muncul lagi.

Berikut ini adalah 7 (Tujuh) alat pengendalian kualitas yang dikemukakan oleh Kaoru Ishikawa.

1) Lembar pengumpul data (Checksheet).

Untuk analisa masalah, diperlukan data yang menggambarkan fakta sebenarnya. Check Sheet adalah suatu formal formulir yang disiapkan untuk pengisian efek. Lembaran pengumpulan dirancang sendiri sesuai keperluan dengan memperhatikan stratifikasi.

2) Grafik (Graph).

Grafik dapat mengetahui berbagai ukuran besar/kecil data yang diperoleh dari dua parameter numeric. Misalnya parameter waktu biaya, waktu persen, waktu hasil kerja, dan sebagainya.

3) Diagram Pareto.

Diagram Pareto adalah diagram balok yang disusun secara berjenjang mulai paling tinggi sampai dengan yang paling rendah dan digunakan untuk menentukan urutan prioritas dari suatu masalah yang akan dipecahkan.

4) Diagram Sebab Akibat (Fish bone).

Diagram sebab akibat (Cause and effect diagram) adalah suatu alat atau tools yang digunakan untuk memecahkan suatu masalah, sangat penting untuk mengetahui penyebab dan hubungan penyebab masalah tersebut. Dengan analisis data dapat diketahui akar penyebab terbesar untuk memecahkan masalah. Sebelah ujung kanan digambarkan efek dan penyebab terbesar efek digambarkan sebelah kiri atas dan bawah garis tengah horizontal efek.

Penyebab-penyebab utama ini kemudian masih mempunyai sub penyebab dan seterusnya hingga tingkat terendah/terkecil. Diagram ini bukan alat statistik (membaca frekuensi kejadian) tetapi menunjukkan variasi penyebab-penyebab.

5) Histogram.

Histogram adalah suatu bentuk grafik yang menunjukan perbedaan data-data. Sebuah histogram menunjukkan distribusi statistikal dengan interval yang sama dari suatu ukuran kualitas. Histogram dipakai dalam analisa stratifikasi untuk menciptakan hipotesis mengapa cacat terjadi.

6) Control chart.

Control Chart adalah suatu grafik dengan batas atas dan batas bawah dalam menentukan kualitas produk yang dihasilkan. Grafik ini bertujuan untuk memantau atau mengetahui kualitas produk yang dihasilkan selama proses produksi berlangsung dan untuk mengetahui jika terjadi ke-abnormal-an pada produk yang dihasilkan.

7) Flow Chart (Diagram Alir).

Flowchart atau Diagram Alir adalah bagan yang digunakan untuk mengambarkan proses-proses operasional sehingga mudah dipahami dan dilihat berdasarkan urutan langkah dari suatu proses ke proses lainnya.

\section{Pengolahan dan Pembahasan Masalah \\ 3.1. Pengolahan Data}

Pada diagram sebab-akibat, dalam menganalisis permasalahan base pallet macet hanya menggunakan $4 \mathrm{M}$ yaitu Man, Material, Machine, Method, karena hanya dengan 4M saja sudah cukup untuk menemukan akar 
permasalahan tersebut.Dari hasil yang didapat pada diagram sebab-akibat, kemudian kita masukan pada tabel why-why solution untuk dicarikan solusi dari hasil analisis permasalahan tersebut. Selain itu dengan menggunakan tabel akan lebih mudah untuk membacanya dan lebih jelas.

Berikut diagram sebab-akibat dapat dilihat pada gambar 1 dan tabel why-why solution (tabel 4W1H) dapat dilihat pada Gambar 1.

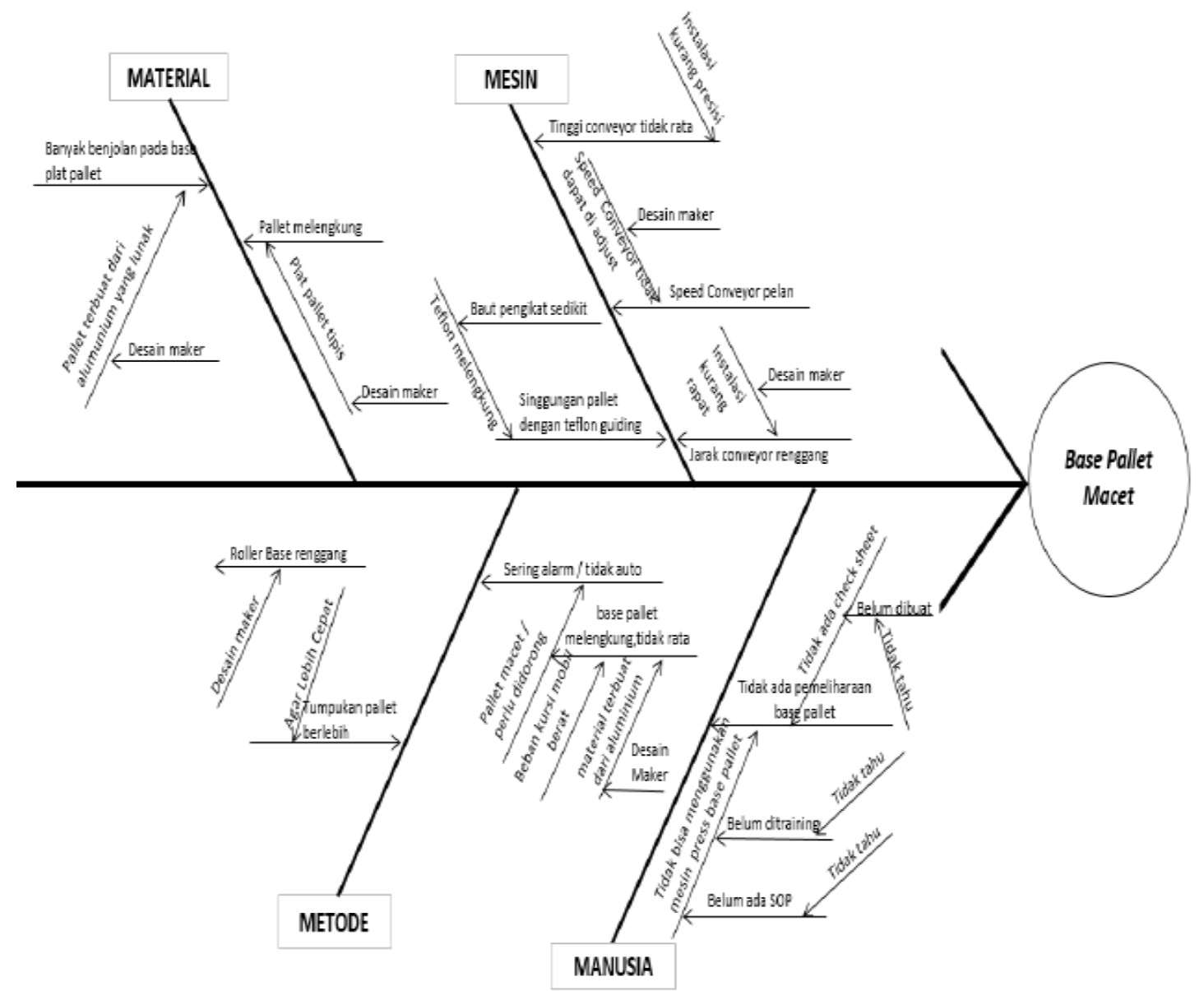

Gambar 1. Diagram Sebab-Akibat Permasalahan Base Pallet Macet di Mesin Conveyor

Dari beberapa permasalahan yang ada, kemudian difikirkan solusinya. Didapatkan beberapa solusi untuk mengatasi permasalahan tersebut yang terdapat pada Gambar 2 yaitu 4W1H. Dari beberapa solusi tersebut kemudian kita pilih salah satu dari solusi tersebut untuk dilakukan.

1) Additional sponge pada shaft roller conveyor.

2) Levelling ulang atau dilakukan kalibrasi untuk semua conveyor.

3) Additional bolt pada teflon atau stopper di sisi conveyor.

4) Membeli mesin press (untuk menge-press frame base pallet yang sudah melengkung).

5) Dibuatkan standarisasi untuk maksimal tumpukan base pallet.

6) Meratakan base pallet yang penyok dengan menggunakan palu (dilakukan oleh operator bagian yang terkait/shipping).

7) Dibuatkan check sheet atau SOP (Standard Operation Procedure) untuk pemeliharaan base pallet.

8) Dilakukan training tentang penggunaan mesin press jikalau mesin sudah dibeli.

9) Additional absorber pada siku atau sudut-sudut frame base pallet.

10) Additional ball roller pada loading dock, dibuat lebih rapat.

Secara garis besar dari permasalahan base pallet macet ditemukan 10 solusi yang akan dilakukan perbaikan, dapat dilihat pada tabel $4 \mathrm{~W} 1 \mathrm{H}$. Kemudian dilakukan penjadwalan kapan, siapa, dimana, berapa biaya yang diperlukan, berapa lama waktu yang diperlukan, apa saja bahan yang diperlukan untuk melakukan pekerjaan tersebut yaitu Additional sponge pada shaft roller conveyor. Adapun perencanaan perbaikan Kasus Base Pallet Macet disajikan pada Gambar 3 dan perhitungan biaya disajikan pada Tabel 1. 


\begin{tabular}{|c|c|c|c|c|c|c|c|}
\hline $\begin{array}{c}\text { OBJEK } \\
\text { PENGAMATAN }\end{array}$ & FAKTOR & IDEAL & ACTUAL & WHY & WHY & WHY & SOLUTION(HOW) \\
\hline \multirow{14}{*}{$\begin{array}{l}\text { Base Pallet } \\
\text { Macet }\end{array}$} & \multirow{4}{*}{ Machine } & $\begin{array}{l}\text { Jalur perlintasan antar } \\
\text { conveyor rapat }\end{array}$ & $\begin{array}{c}\text { Jalur perlintasan antar conveyor } \\
\text { renggang (masih terdapat celah } \\
\text { yang cukup jauh) }\end{array}$ & Proses instalasi kurang rapat & Desain maker & & $\begin{array}{l}\text { Aditional sponge pada shaft } \\
\text { roller conveyor }\end{array}$ \\
\hline & & Tinggi antar conveyor rata & Tinggi antar conveyor tidak rata & $\begin{array}{c}\text { Proses instalasi tidak sama } \\
\text { tingginya }\end{array}$ & $\begin{array}{l}\text { Leveling kurang presisi / } \\
\text { tidak pakai water pass }\end{array}$ & & $\begin{array}{l}\text { Leveling ulang dengan } \\
\text { water pass }\end{array}$ \\
\hline & & \begin{tabular}{|c|} 
Stopper samping conveyor \\
untuk memperlancar jalannya \\
pallet
\end{tabular} & $\begin{array}{l}\text { Pallet macet karena } \\
\text { bersinggungan dengan teflon } \\
\text { stopper samping conveyor }\end{array}$ & $\begin{array}{c}\text { Teflon stopper samping } \\
\text { conveyor memuai/melengkung }\end{array}$ & $\begin{array}{l}\text { Baut pengikat teflon } \\
\text { sedikit }\end{array}$ & & $\begin{array}{l}\text { Berikan tambahan baut } \\
\text { pengikat teflon }\end{array}$ \\
\hline & & $\begin{array}{c}\text { Speed motor conveyor dapat di } \\
\text { adjust sesuai dengan } \\
\text { kebutuhan }\end{array}$ & Speed conveyor pelan & $\begin{array}{l}\text { Speed motor conveyor tidak } \\
\text { dapat di adjust }\end{array}$ & Desain Maker & & - \\
\hline & \multirow{3}{*}{ Methode } & \multirow{2}{*}{$\begin{array}{l}\text { Pallet bejalan diatas conveyor } \\
\text { dengan lancar secara otomatis }\end{array}$} & \multirow{2}{*}{$\begin{array}{c}\text { Sering alarm Base Pallet sering } \\
\text { berhenti, manual dorong }\end{array}$} & \multirow{2}{*}{$\begin{array}{c}\text { Base pallet melengkung, bagian } \\
\text { bawah base pallet tidak rata }\end{array}$} & $\begin{array}{c}\text { Beban kursi mobil yang } \\
\text { berat }\end{array}$ & & \multirow{2}{*}{$\begin{array}{l}\text { Press base pallet dan yang } \\
\text { tidak rata di getok dengan } \\
\text { menggunakan palu karet }\end{array}$} \\
\hline & & & & & $\begin{array}{c}\text { Base pallet terbuat dari } \\
\text { alumunium, lunak }\end{array}$ & Desain maker & \\
\hline & & Tumpukan pallet maksimal 6 & Tumpukan pallet lebih dari 6 & Agar lebih cepat & & & $\begin{array}{c}\text { Dibuatkan standarisasi } \\
\text { untuk tumpukan max base }\end{array}$ \\
\hline & \multirow{2}{*}{ Material } & $\begin{array}{l}\text { Plat dasar pallet tebal dan } \\
\text { tidak mudah berubah bentuk }\end{array}$ & $\begin{array}{c}\text { Plat dasar pallet tipis dan mudah } \\
\text { berubah bentuk (banyak } \\
\text { benjolan akibat pemakaian) }\end{array}$ & $\begin{array}{c}\text { Plat dasar pallet terbuat dan } \\
\text { alumunium }\end{array}$ & Desain maker & & $\begin{array}{c}\text { Ratakan benjolan-benjolan } \\
\text { dengan palu }\end{array}$ \\
\hline & & Pallet tidak melengkung & Pallet melengkung & $\begin{array}{c}\text { Plat dasar pallet tipis dan } \\
\text { mudah berubah bentuk (banyak } \\
\text { benjolan akibat pemakaian) }\end{array}$ & $\begin{array}{l}\text { Plat dasar pallet terbuat } \\
\text { dari alumunium }\end{array}$ & Desai Maker & $\begin{array}{l}\text { Press pallet yang } \\
\text { melengkung }\end{array}$ \\
\hline & \multirow{3}{*}{ Man } & \multirow{3}{*}{$\begin{array}{l}\text { Dapat melakukan perawatan } \\
\text { pallet dengan mesin press }\end{array}$} & \multirow{3}{*}{$\begin{array}{l}\text { Tidak dapat melakukan } \\
\text { perawatan }\end{array}$} & $\begin{array}{l}\text { Tidak ada check sheet } \\
\text { pemeliharaan base pallet }\end{array}$ & Belum dibuat & Tidak tahu & $\begin{array}{c}\text { Dibuatkan SOP untuk } \\
\text { pemeliharaan base pallet }\end{array}$ \\
\hline & & & & \multirow{2}{*}{$\begin{array}{c}\text { Tidak bisa menggunakan mesin } \\
\text { press pallet }\end{array}$} & Belum ada training & Tidak tahu & $\begin{array}{l}\text { Training cara menggunakan } \\
\text { mesin press base pallet }\end{array}$ \\
\hline & & & & & Belum ada SOP & Tidak tahu & Dibuatkan SOP \\
\hline & \multirow[t]{2}{*}{ Environment } & $\begin{array}{l}\text { Loading pallet dari stoker ke } \\
\text { truk tidak menurun tajam }\end{array}$ & $\begin{array}{c}\text { Loading pallet dari stoker ke truk } \\
\text { menurun tajam }\end{array}$ & $\begin{array}{c}\text { untuk mempermudah proses } \\
\text { loading dari stoker ke truk tanpa } \\
\text { menggunakan mesin/motor } \\
\text { conveyor }\end{array}$ & Desain maker & & $\begin{array}{c}\text { Aditional absorber stopper } \\
\text { pallet }\end{array}$ \\
\hline & & $\begin{array}{l}\text { Roller base pada dok loading } \\
\text { pallet dari truk jaraknya rapat }\end{array}$ & $\begin{array}{l}\text { Roller base pada dok loading } \\
\text { pallet dari truk renggang }\end{array}$ & Desain maker & & & $\begin{array}{c}\text { Additional ball roller, jarak } \\
\text { dibuat lebih rapat }\end{array}$ \\
\hline
\end{tabular}

Gambar 2. 4W1H Permasalahan Base Pallet Macet di Mesin Conveyor Storage

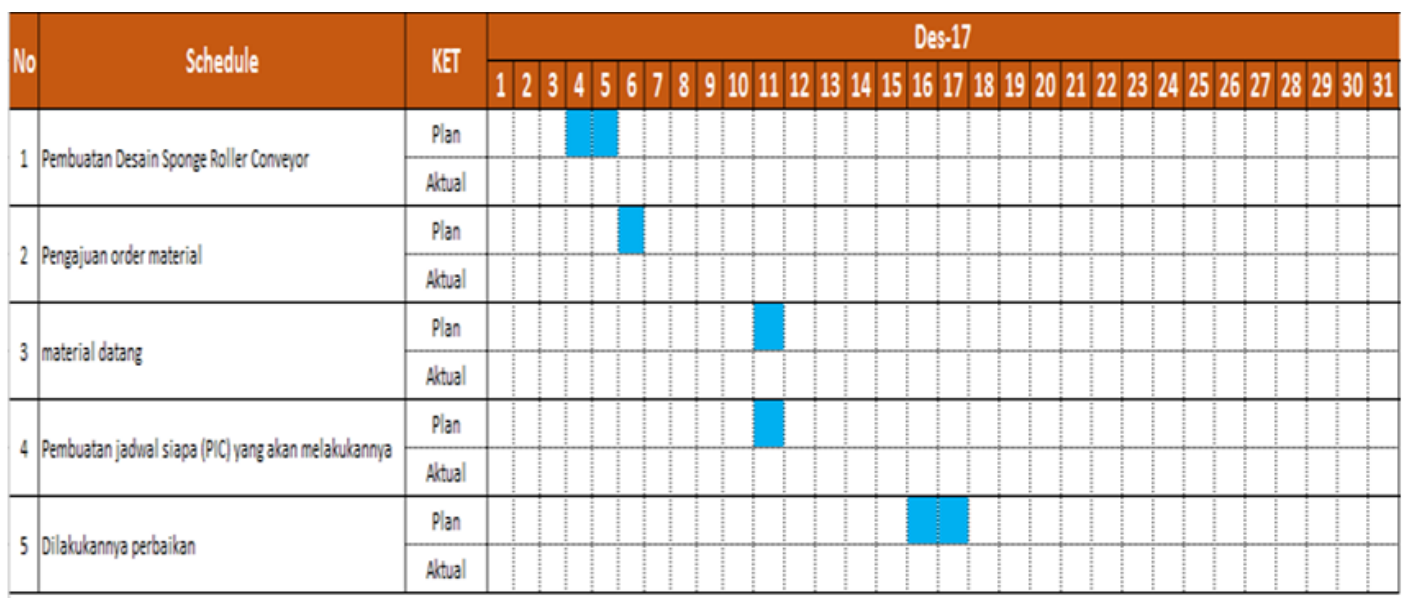

Gambar 3. Perencanaan Dilakukannya Perbaikan Kasus Base Pallet Macet

Tabel 1. Rincian Biaya Pembelian Bahan Material

\begin{tabular}{|l|l|l|l|l|}
\hline No & Item & Satuan & Harga/unit & Total Harga \\
\hline 1 & Sponge/busa padat & 6 meter & Rp 15.000 & $\operatorname{Rp~} 90.000$ \\
\hline 2 & Lem Aibon & 1 kaleng/1kg & $\operatorname{Rp~65.000~}$ & $\operatorname{Rp~} 65.000$ \\
\hline 3 & Cutter & 2 buah & Rp 12.000 & $\operatorname{Rp~} 24.000$ \\
\hline \multicolumn{2}{|l}{ Total } & $\operatorname{Rp~} 179.000$ \\
\hline
\end{tabular}

Proses pembuatan desain penambahan sponge pada shaft roller conveyor telah dilakukan pengukuran sesuai aktual pada mesin (studi lapangan), sebagaimana disajikan pada Gambar 4. Dengan dibuatnya perbaikan ini (penambahan sponge pada shaft roller conveyor) supaya dapat menambah power saat proses perpindahan station dan dapat mengurangi permasalahan base pallet yang banyak macet di mesin conveyor storage.

Pelaksanaan perbaikan dilakukan sesuai dengan jadwal yang telah dibuat yaitu pemasangan atau penambahan sponge pada shaft roller conveyor. Berikut Gambar sebelum dan sesudah dilakukan penambahan atau pemasangan sponge pada shaft roller conveyor, disajikan pada Gambar 5, Gambar 6 dan Gambar 7. 


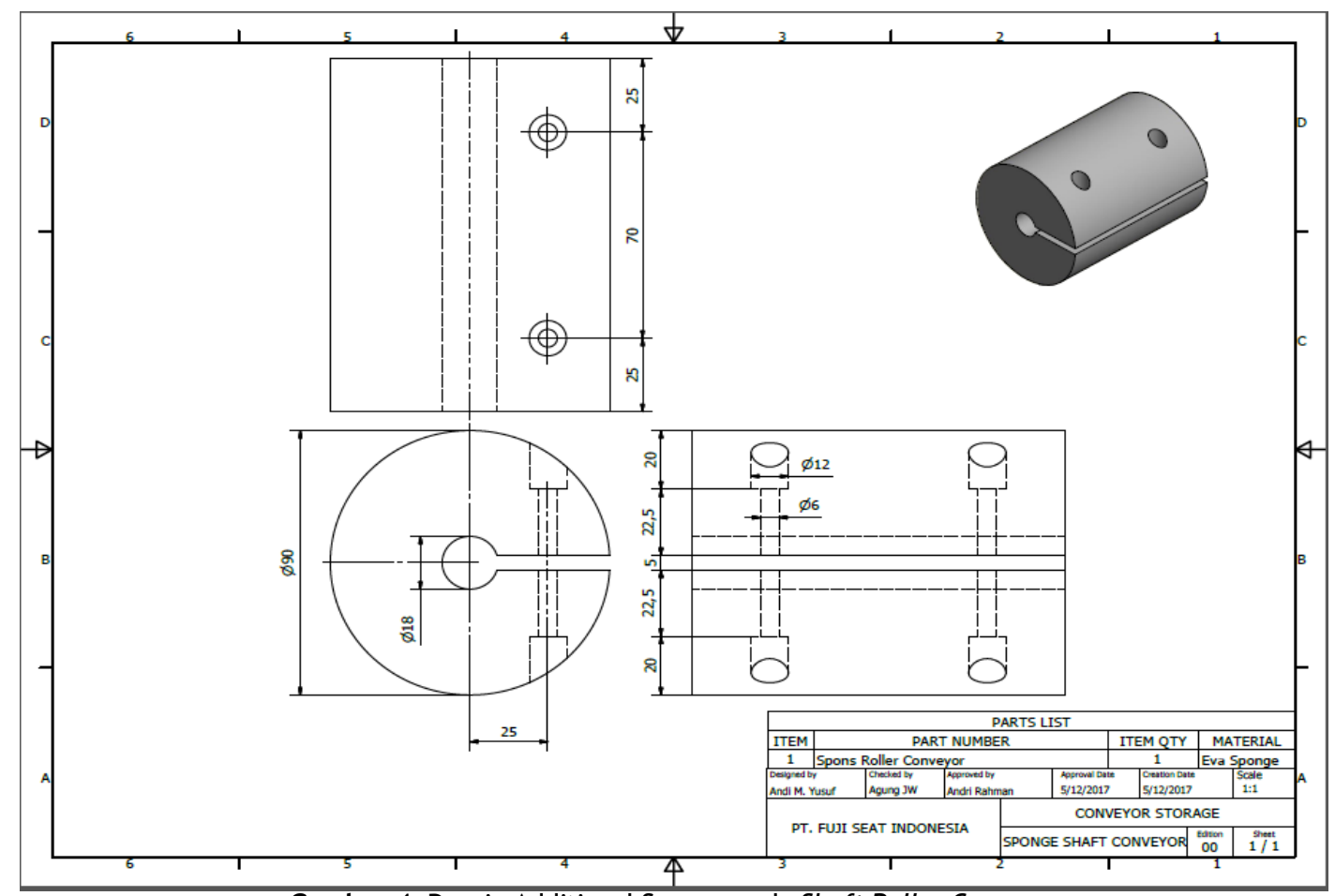

Gambar 4. Desain Additional Sponge pada Shaft Roller Conveyor

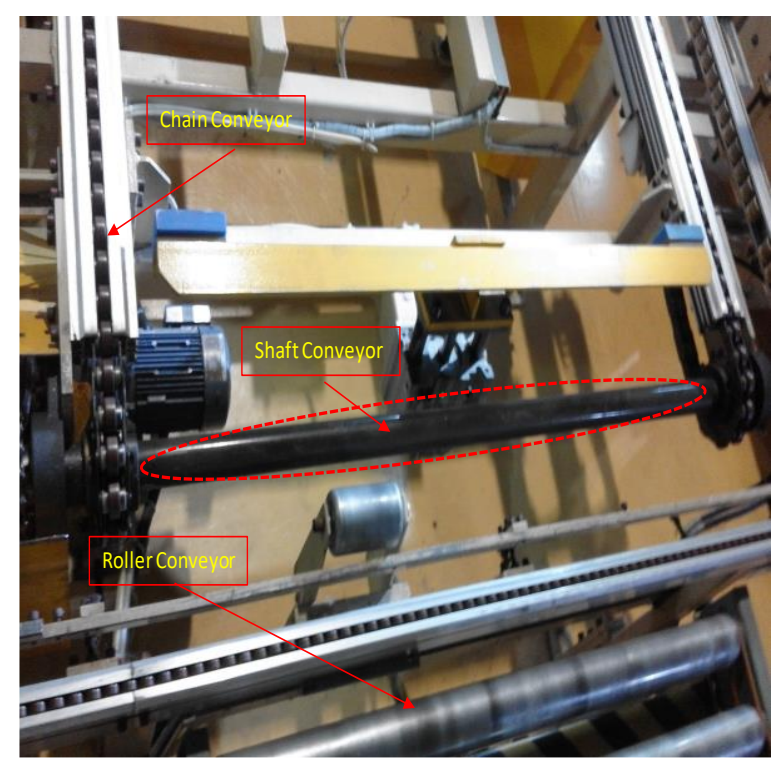

Gambar 5. Sebelum Dilakukan Penambahan Shaft Roller Conveyor

\subsection{Analisis Perbandingan Sebelum dan Sesudah Perbaikan}

Setelah dilakukan perbaikan dengan penambahan sponge pada shaft roller conveyor kemudian dilakukan analisis kembali apakah dari hasil perbaikan tersebut hasilnya signifikan atau tidak?

Dari gambar grafik sebelum dan sesudah dilakukan perbaikan, dapat dilihat data saat sebelum dilakukan perbaikan dari bulan september 2017 sampai dengan di minggu kedua bulan desember 2017 pada Gambar 6 . Data yang diperoleh untuk kasus base pallet macet di mesin conveyor storage cukup tinggi bahkan melampaui dari target toleransi yang telah ditetapkan sebelum dilakukan perbaikan.

Berdasarkan data tersebut dapat dijelaskan yaitu untuk data di bulan September 2017 diminggu pertama ada 687 base pallet macet, minggu kedua ada 678 base pallet macet, minggu ketiga ada 809 base pallet macet, minggu keempat ada 564 base pallet macet dan minggu kelima ada 629 base pallet macet. Jadi untuk total base pallet macet selama bulan september 2017 sebanyak 3367 base pallet macet. Pada bulan Oktober 2017 diminggu pertama base pallet macet ada 597 base pallet macet, minggu kedua ada 666 base pallet macet, minggu ketiga ada 619 base pallet macet, minggu keempat ada 521 base pallet macet dan minggu 
kelima ada 566 base pallet macet. Jadi total keseluruhan base pallet macet selama bulan oktober 2017 sebanyak 2969 base pallet macet.

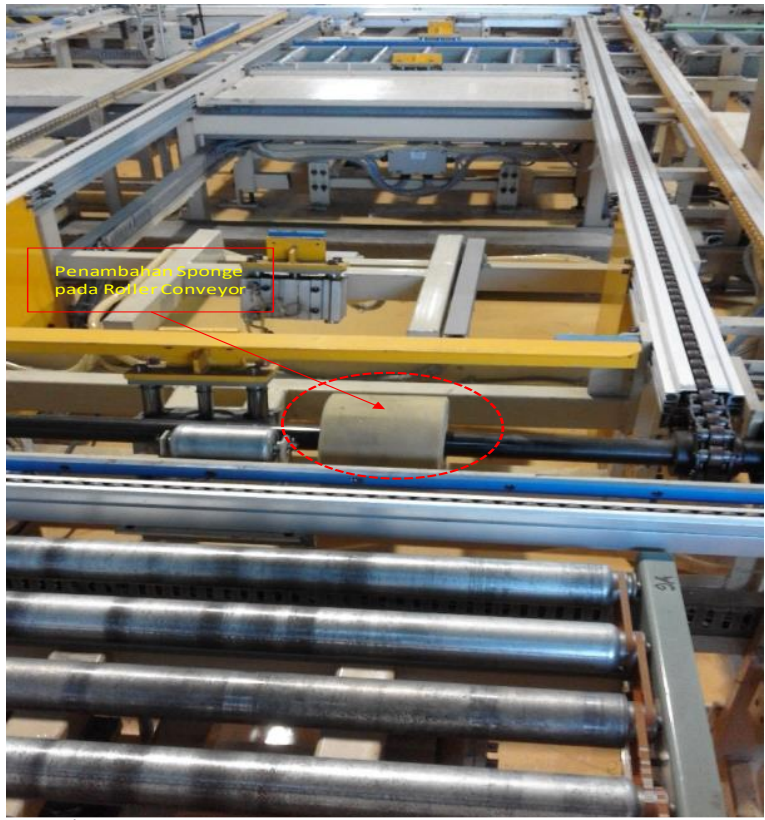

Gambar 6. Setelah Dilakukan Penambahan Sponge pada Shaft Roller Conveyor (Additional 1)

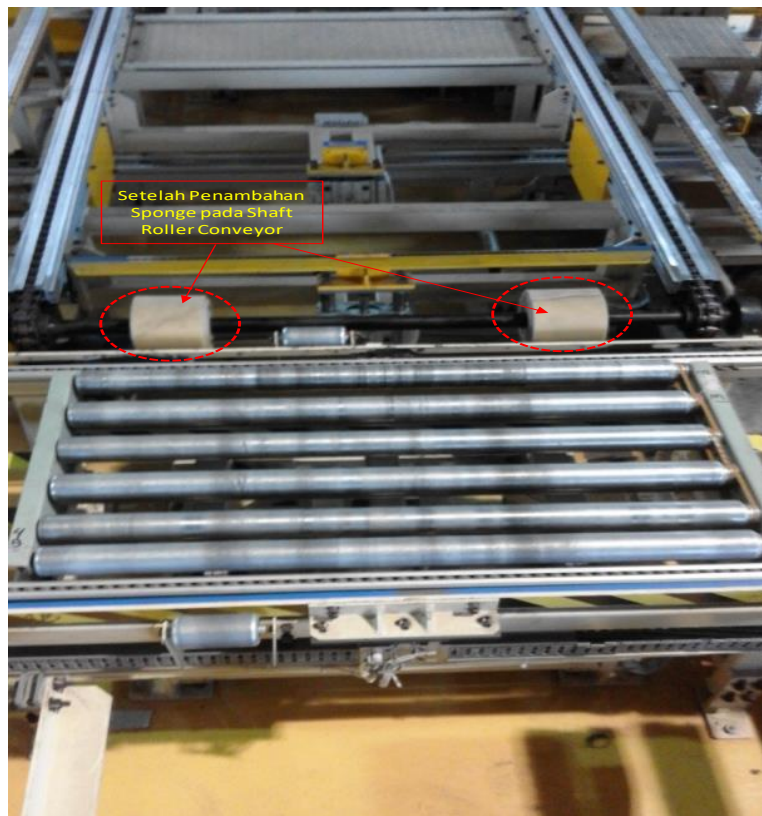

Gambar 7. Setelah Dilakukan Penambahan Sponge pada Shaft Roller Conveyor (Additional 2)

Sedangkan pada bulan November 2017 base pallet macet yaitu, diminggu pertama ada 482 base pallet macet, diminggu kedua ada 679 base pallet macet, diminggu ketiga ada 597 base pallet macet, diminggu keempat ada 713 base pallet macet dan diminggu kelima ada 819 base pallet macet. Jadi total keseluruhan base pallet macet selama bulan november 2017 sebanyak 3290 base pallet macet.

Pada Desember 2017 yaitu 611 base pallet macet diminggu pertama dan 671 base pallet macet diminggu kedua. Jadi total keseluruhan base pallet macet selama dua minggu di bulan desember 2017 sebanyak 1282 kasus base pallet macet. Untuk diminggu ketiga dan keempat telah dilakukan perbaikan, pada minggu ketiga sebanyak 240 base pallet macet dan pada minggu keempat sebanyak 248 base pallet macet.

Dari perbaikan yang awalnya menggunakan busa padat (sponge), kemudian dikembangkan lagi yaitu dengan menggunakan bahan yang terbuat dari karet. Karena diawal perbaikan menggunakan busa padat (sponge) itu hanya sebagai sementara. Terdapat kelemahan juga jika menggunakan busa padat (sponge) yaitu lebih cepat aus (terkikis), jadi akan lebih sering dilakukan penggantian untuk kedepannya. Sedangkan untuk penggunaan bahan material yang terbuat dari karet akan lebih awet atau life time lebih lama, sehingga tidak akan terlalu sering melakukan penggantian, sebagaimana disajikan pada Gambar 9.

Pada Gambar 9 yaitu setelah dilakukan penggantian sponge dengan menggunakan material dari bahan karet (additional 1). Pada gambar tersebut terlihat hanya ada satu penambahan saja, dikarenakan di area tersebut cukup hanya ditambahkan satu saja karena base pallet hanya diisi oleh kursi mobil bagian paling belakang ( 1 kursi mobil saja) dan beban juga tidak terlalu berat.

Kemudian pada gambar 10 yaitu setelah dilakukan penggantian sponge dengan menggunakan material dari bahan karet (additional 2). Pada gambar tersebut terlihat ada dua penambahan sponge (bahan karet), dikarenakan di area tersebut jika hanya ditambahkan satu saja, power yang dihasilkan kurang kuat karena di area tersebut dilintasi oleh base pallet yang diisi oleh 3 sampai 4 kursi mobil dan memiliki beban yang cukup berat.

\section{Kesimpulan}

Kesimpulan dari hasil akhir penelitian berdasarkan hasil analisis dan untuk menjawab rumusan masalah penelitian adalah sebagai berikut:

1) Penyebab terjadinya delay delivery pada proses shipping kursi mobil di mesin conveyor storage adalah banyaknya base pallet yang macet di mesin conveyor storage. Persentase dari base pallet macet di mesin conveyor storage sebesar $72.79 \%$ dari total permasalahan-permasalahan penyumbang terjadinya delay delivery. 
2) Dilakukan perbaikan untuk mengatasi atau mengurangi frekuensi permasalahan base pallet macet di mesin conveyor storage dengan menambahkan sponge ataw karet pada shaft roller conveyor. Penambahan gulungan sponge tersebut dimaksudkan untuk menambah power saat perpindahan base pallet antar station.

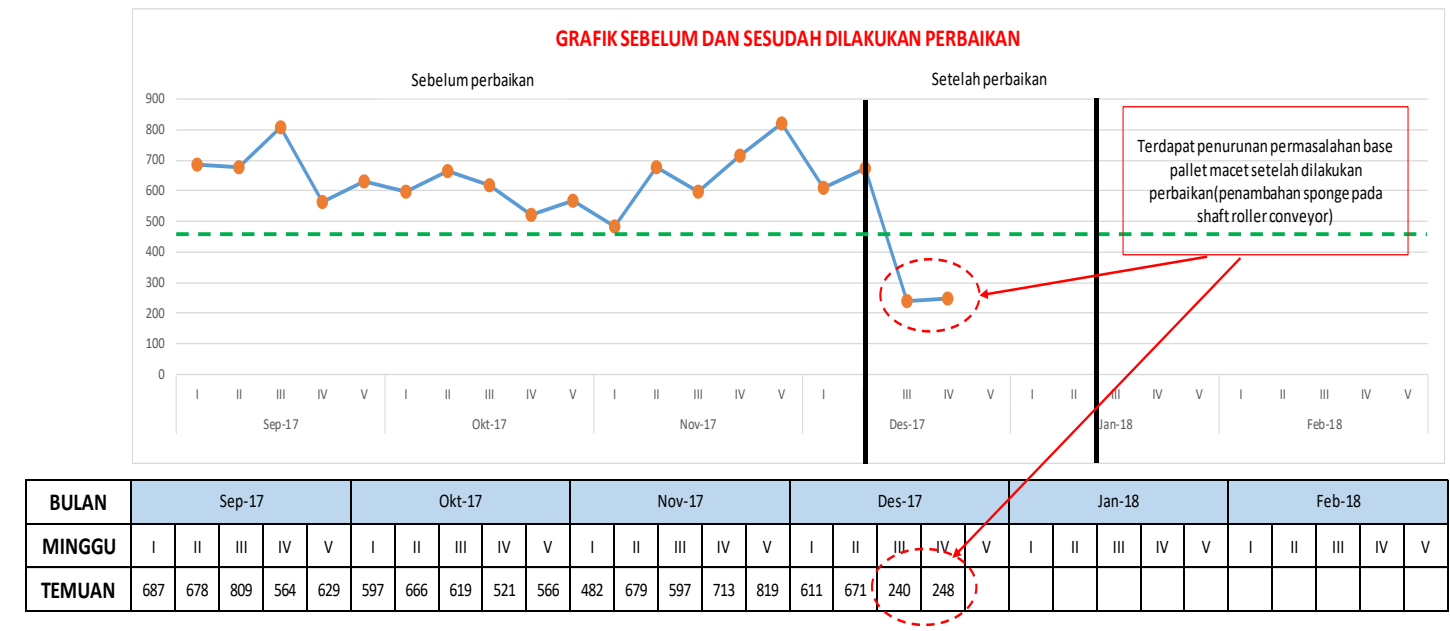

Gambar 8. Grafik Sebelum dan Sesudah Dilakukan Perbaikan Pengembangan Hasil Perbaikan Dengan Menggunakan Material dari Karet

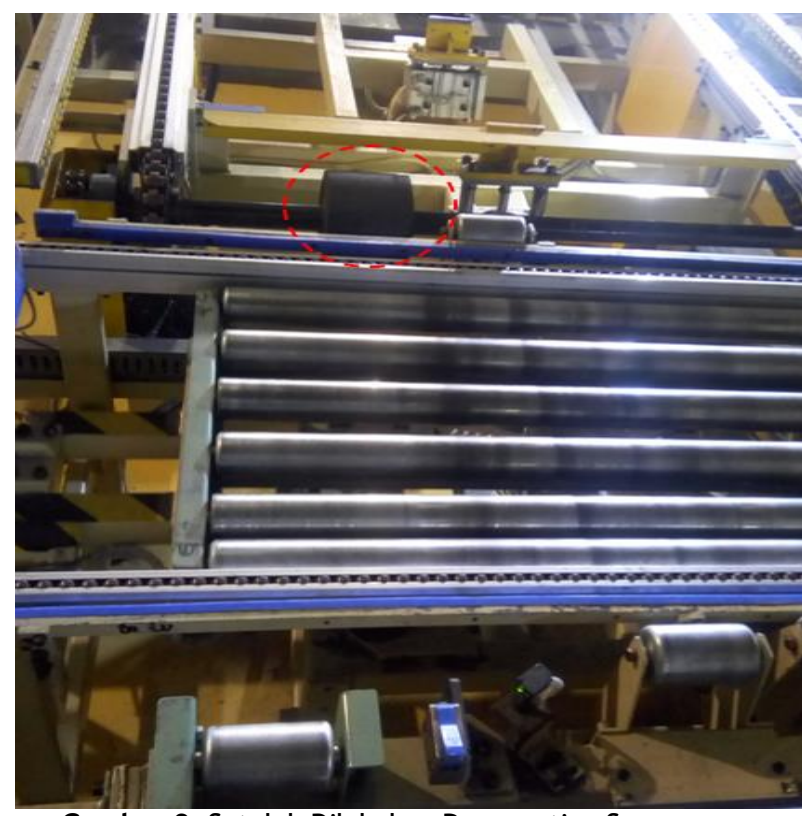

Gambar 9. Setelah Dilakukan Penggantian Sponge dengan Menggunakan Material Dari Bahan Karet (Additional 1 sponge)
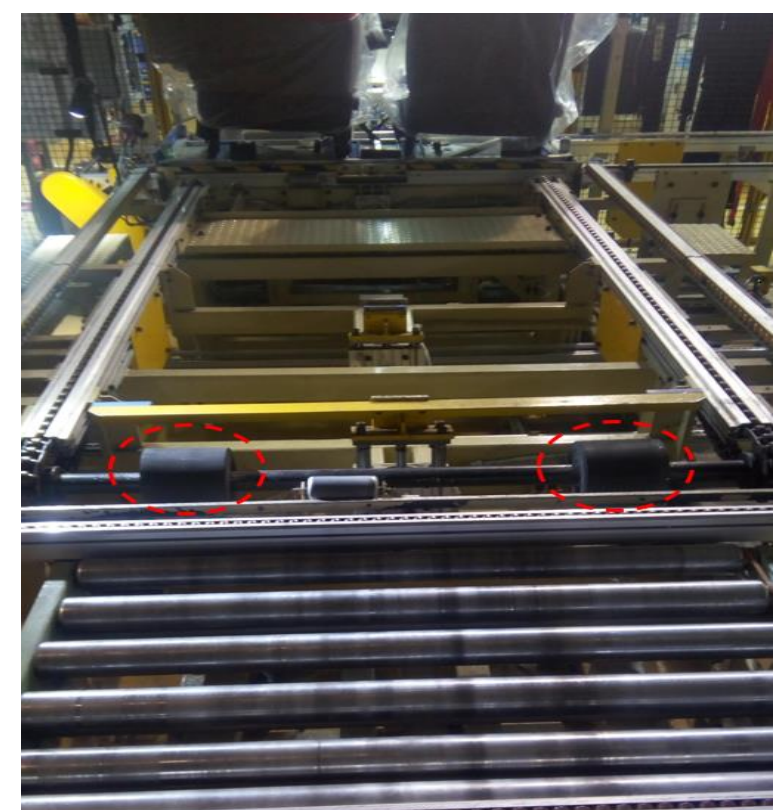

Gambar 10. Setelah Dilakukan Penggantian Sponge Dengan Menggunakan Material Dari Bahan Karet (Additional 2 sponge)

\section{Daftar Pustaka}

1. Assauri, S., 2004. Manajemen Pemasaran. Jakarta: Rajawali Press.

2. Ishikawa, K., 1985. Pengendalian Mutu Terpadu (Terjemahan). Bandung: CV. Remaja Maju.

3. Pheng, L.S., dan Hui, M.S., 2004. Implementing and Applying Six Sigma in Construction. Journal of construction engineering and management, Vol 130 (4), hal 482-489.

4. Pande, P.S. Neuman, R.P, Cavanagh, R.R., 2002. The Six Sigma Way : Bagaimana GE, Motorola dan Perusahaan Terkenal Lainya Mengasah Kinerja Mereka. Andi. Yogyakarta.

5. Pyzdek, T., 2000. The Six Sigma Handbook. Jakarta: Salemba Empat. 